\title{
Quick Analysis of Organic Amendments via Portable X-ray Fluorescence Spectrometry
}

\author{
Rafael López-Núñez ${ }^{1} * \mathbb{1}$, Fátima Ajmal-Poley ${ }^{1}$, José A. González-Pérez ${ }^{1}[$, \\ Miguel Angel Bello-López ${ }^{2}$ and Pilar Burgos-Doménech ${ }^{1}$ \\ 1 Instituto de Recursos Naturales y Agrobiología de Sevilla (IRNAS-CSIC), Avda. Reina Mercedes 10, \\ 41012 Sevilla, Spain; fatima.ap94@gmail.com (F.A.-P.); jag@irnase.csic.es (J.A.G.-P.); \\ pburgos@irnase.csic.es (P.B.-D.) \\ 2 Department of Analytical Chemistry, Faculty of Chemistry, Universidad de Sevilla, c/Prof. García González, \\ s/n, 41012 Sevilla, Spain; mabello@us.es \\ * Correspondence: rafael.lopez@csic.es
}

Received: 17 September 2019; Accepted: 30 October 2019; Published: 6 November 2019

check for updates

\begin{abstract}
The determination of heavy metals in soils and organic amendments, such as compost, manure, biofertilizer, and sludge, generally involves the digestion of samples with aqua regia, and the determination of those in the solution using various techniques. Portable X-ray fluorescence (PXRF) has many advantages in relation to traditional analytical techniques. However, PXRF determines the total elemental content and, until now, its use for the analysis of organic amendments has been limited. The objective of this work is the calibration of a PXRF instrument to determine the aqua regia-soluble elemental contents directly in solid samples of organic amendments. Our proposal will avoid the digestion step and the use of other laboratory techniques. Using a training set of samples, calibration functions were obtained that allow the determination of the aqua regia-soluble contents from the PXRF readings of total contents. The calibration functions (obtained by multiple linear regression) allowed the quantitative determination of the aqua regia-soluble contents of $\mathrm{Fe}, \mathrm{K}, \mathrm{P}, \mathrm{S}, \mathrm{Zn}$, $\mathrm{Cu}, \mathrm{Pb}, \mathrm{Sr}, \mathrm{Cr}$, and $\mathrm{Mn}$, as well as the organic matter content and a semi-quantitative assessment of $\mathrm{Al}$, $\mathrm{Ca}, \mathrm{V}, \mathrm{Ba}, \mathrm{Ni}$, and $\mathrm{As}$ contents. The readings of $\mathrm{Si}, \mathrm{Fe}, \mathrm{Al}, \mathrm{Ca}, \mathrm{K}$, or $\mathrm{S}$ were used as correction factors, indicating that the calibrations functions found are truly based on the chemical composition of the sample matrix. This study will allow a fast, cheap, and reliable field analysis of organic amendments and of other biomass-based materials.
\end{abstract}

Keywords: compost; sewage sludge; aqua regia-soluble content; heavy metal; urban garden; loss on ignition; organic matter determination; multiple linear regression

\section{Introduction}

Urban agriculture is a growing activity in many cities on a worldwide scale [1,2]. Urban agriculture is practised in both developed and developing economies, although it can serve different purposes in different places, such as recreation or food security [3]. Under both approaches, there is a revitalised interest in research concerning urban agriculture from a variety of perspectives, including landscaping and urban planning [4], social and economic aspects [5], health and the environment [6], as well as technical subjects [7].

There is debate over the advantages and disadvantages of urban agriculture. There are many well-documented benefits of urban agriculture: subsistence survival, food sovereignty and security, reduced food transportation distance, carbon sequestration, a potentially reduced urban heat island effect, improved physical and mental health, improved aesthetics, community building, employment 
opportunities, improved local land prices, shortened supply chains, and, thus, reduced price differentials between producers and consumers, provision of habitats for wildlife, and waste recycling [8].

A major concern of urban agriculture lies in risks related to the eventual pollution of urban products. Fruits and vegetables grown in cities could be polluted by undesirable organic or inorganic substances [2], and there are several studies that have focused on trace elements found in urban fruits and vegetables. Metals can reach vegetables through different pathways, one of them being the use of polluted fertilizers, composts, sewage sludge, and livestock manure [9]. The reviews of Alloway [9] and Wei and Yang [10] reported on anthropogenic sources of metal contamination.

The determination of heavy metals in soils and organic amendments generally involves the digestion of samples with aqua regia, and the determination of those in the solution using various analytical techniques such as ICP-OES, atomic absorption, and others. Urban gardeners generally lack the financial and technical requirements necessary to test metal contamination in their soils and amendments using these analytical techniques.

Recently, improvements in X-ray tube and detector technologies have resulted in field-portable instruments, such as portable X-ray fluorescence (PXRF), that enable such uses as geologic investigations [11], as well as having environmental, pedological, and agronomic applications [12]. PXRF has many advantages in relation to traditional analytical techniques and is less expensive. PXRF analysis is non-destructive and very fast, with a simple or no sample treatment. The instrument could be used in the laboratory or in the field. The technique has a wide range of quantifications, having detection limits poorer than those of large laboratory-based XRF instruments or of ICP techniques, but it is sufficient for environmental monitoring of a large number of elements that can be determined simultaneously $[12,13]$. Despite lower detection limits of the chemical methods, sometimes these become more imprecise and inaccurate than XRF spectrometry, mainly due to the fact that the latter requires virtually no sample pretreatment [14]. There are approved protocols for using this instrument in soils and sediments $[15,16]$. Recently, Caporale et al. [17] evaluated the possibility of assessing the aqua regia-extractable content of metals from a multi-element profile of the soil using a PXRF analyser. These authors indicated that the discrepancy between the 'pseudototal' metal contents measured in soil samples by aqua regia and the 'total' contents measured by PXRF strongly depended on the properties of the element to be analysed, the chemical and mineralogical composition of the soil matrix, the organic matter content as well as of the type of acid used in the total extraction. Sharma et al. [18] applied multiple linear regression to a modeling dataset to establish the relationship between lab-determined soil Cation Exchange Capacity and eight variables from PXRF elemental data. They further improved the model using auxiliary input data (soil clay, $\mathrm{pH}$, organic matter) as modeling variables; when using only clay, organic matter, and two elements $(\mathrm{Cr}, \mathrm{Ni})$ to make the prediction they obtained better regression coefficients.

Despite the possibilities of this technique, until now its use for the analysis of compost and organic amendments has been limited to a few investigations [19-24], and the possibility for quantitative determination has been limited to a few elements. McWhirt et al. [22] and Havukainen et al. [23] found only eight elements that could be quantitatively determined in dry samples, and only qualitative results were obtained for a few more. They indicated that both the physical and the chemical properties of the samples affected measurement accuracy; significant influences due to moisture content, particle size, sample heterogeneity, positioning of samples, matrix effects (e.g., inter-element effects), calibration and reference standards, sample pre-treatment (e.g., drying, sieving, and homogenization), and the organic content of the sample were found.

Nevertheless, these studies concluded that there is a great potential for widespread evaluation and definitive quantification of elemental concentrations, and that the lower cost, faster speed, and the portability of PXRF may outweigh the slight loss of accuracy, especially when the field evaluation of composted materials is a primary objective.

We hypothesized that elemental data obtained from PXRF analyser can serve as a proxy for aqua regia-soluble contents of organic amendments. We also hypothesized that aqua regia-soluble contents 
could be reliably determined using multiple linear regression including correction terms based on the contents of major elements, such as $\mathrm{Si}$ and Fe. The objective of this work is the calibration of a PXRF instrument to determine the aqua regia-soluble elemental contents, directly from solid samples of organic amendments, avoiding previous digestion processes and the use of other laboratory techniques. Using a training set of samples, calibration functions based on multiple linear regression will be obtained that could allow the determination of the aqua regia-soluble contents from the PXRF readings of the total contents.

To the authors' knowledge, such an approach has not been used to date. Not even in the case of soils, in which the relationship between PXRF and aqua regia-extractable contents has been more studied, has this correction been proposed, despite Si being a frequent element in soils.

\section{Materials and Methods}

\subsection{Field Portable X-ray Fluorescence (PXRF) Analysis}

The analyzer Niton XL3t 950s GOLDD + XRF (Thermo Scientific Inc., Billerica, MA, USA), with its laboratory stand, was used in this study. The analyzer was equipped with an X-ray tube with an $\mathrm{Ag}$ anode, operated at $50 \mathrm{keV}, 200 \mu \mathrm{A}$, and $2 \mathrm{~W}$, with a geometrically optimized large Si drift detector (GOLDD). The analyzer can measure a range of elements, from Mg to U. Two factory calibration modes, known as the Mining (M) mode and the Soils (S) mode, were used for the measurements. In the M mode the following elements could be detected: $\mathrm{Ba}, \mathrm{Sn}, \mathrm{Cd}, \mathrm{Pd}, \mathrm{Ag}, \mathrm{Mo}, \mathrm{Nb}, \mathrm{Zr}, \mathrm{Sr}, \mathrm{Bi}, \mathrm{As}, \mathrm{Se}, \mathrm{Hg}, \mathrm{W}$, $\mathrm{Pb}, \mathrm{Zn}, \mathrm{Cu}, \mathrm{Ni}, \mathrm{Co}, \mathrm{Fe}, \mathrm{Mn}, \mathrm{Cr}, \mathrm{V}, \mathrm{Ti}, \mathrm{Ca}, \mathrm{Cl}, \mathrm{K}, \mathrm{S}, \mathrm{P}, \mathrm{Si}$, and $\mathrm{Al}$. The $\mathrm{S}$ mode is recommended for soil metallic elements at low concentrations, and the following elements could be detected: $\mathrm{Ba}, \mathrm{Sb}, \mathrm{Sn}, \mathrm{Cd}$, $\mathrm{Ag}, \mathrm{Mo}, \mathrm{Zr}, \mathrm{Sr}, \mathrm{U}, \mathrm{Rb}, \mathrm{Th}, \mathrm{Pb}, \mathrm{Se}, \mathrm{As}, \mathrm{Tl}, \mathrm{Hg}, \mathrm{Zn}, \mathrm{Cu}, \mathrm{Ni}, \mathrm{Co}, \mathrm{Fe}, \mathrm{Mn}, \mathrm{Cr}, \mathrm{V}, \mathrm{Ti}, \mathrm{Ca}, \mathrm{K}, \mathrm{Cl}, \mathrm{S}$, and P.

Dried and finely ground samples were measured by filling an XRF container (model SC-4331, $26 \mathrm{~mm}$ internal diameter, $24 \mathrm{~mm}$ height, Premier Lab Supply Inc., Port St. Lucie, FL, USA) capped with a $4 \mu \mathrm{m}$ propylene film (model 240-255, $63 \mathrm{~mm}$ diameter, Premier Lab Supply Inc., Port St. Lucie, FL, USA). The samples were scanned in triplicate in each of the $M$ and $S$ modes and the average elemental content for each mode used hereafter. The analysis time for each scan was $90 \mathrm{~s}$ for the $\mathrm{S}$ mode and $120 \mathrm{~s}$ for the M mode.

\subsection{Samples}

The samples of organic amendments corresponded to the MARSEP program, which is part of the Wageningen Evaluating Programmes for Analytical Laboratories (WEPAL) [25]. Samples corresponding to the quarterly periods one and three of 2015 to 2018 (32 samples, 4 per period) were included. The materials analyzed were composts (14 samples), sludge (12 samples), organic fertilizers (4 samples), and manures (2 samples) from four different European countries, and they were received as a dried and finely crushed powder. The dry test samples have been shown to be stable over a number of years when stored at room temperature.

In the MARSEP programme, elements were determined as the acid-extractable form, $\mathrm{X}$ (ae), being aqua regia the most common extractant $[26,27]$, although other extractants such as $\mathrm{HNO}_{3}$ or $\mathrm{HNO}_{3} / \mathrm{H}_{2} \mathrm{O}_{2}$ were used by a few participating laboratories. The elements considered were $\mathrm{As}, \mathrm{Ba}, \mathrm{Ca}, \mathrm{Cd}, \mathrm{Co}, \mathrm{Cr}$, $\mathrm{Cu}, \mathrm{Fe}, \mathrm{Hg}, \mathrm{K}, \mathrm{Mg}, \mathrm{Mn}, \mathrm{Mo}, \mathrm{Na}, \mathrm{Ni}, \mathrm{P}, \mathrm{Pb}, \mathrm{S}, \mathrm{Sb}, \mathrm{Se}, \mathrm{Si}, \mathrm{Sn}, \mathrm{Sr}, \mathrm{Ti}, \mathrm{V}$, and $\mathrm{Zn}$. Loss on ignition (LOI, i.e., organic matter) was also included. It was assumed that the MARSEP samples can be considered as Certified Reference Materials and that the average value for each determined element [28] obtained from the set of individual values of the participating laboratories was the "true value" for the element. The number of individual data used to calculate the average varied to a maximum of approximately 30 , and depended on the element. Average values using less than $n=5$ were not considered in this study. It is doubtful which of the two methods provided by the PXRF instrument, Soil or Mining, offers better results in relation to the determination of the majority elements $(\mathrm{Fe}, \mathrm{Al}, \mathrm{Ca}, \mathrm{K}, \mathrm{P}, \mathrm{S})$, the concentrations of which ranged in the order of percentage. There are very few cases of use of the same model of 
instrument for the analysis of waste samples in the literature. Havukainen et al. [23] used the Mining method, but their findings indicate that there is not an acceptable level of agreement between PXRF and aqua regia-ICPMS for the examined element measurements, since the differences are too large.

Two additional reference materials were used to assess the performance of the PXRF instrument for the determination of the real total content of major elements ( $\mathrm{Fe}, \mathrm{Al}, \mathrm{Ca}, \mathrm{K}, \mathrm{P}, \mathrm{S}$, and $\mathrm{Si}$ ). These samples were a sediment sample from the ISE (International Soil-Analytical Exchange) Programme (sample no. 859, period 2017.2.3, collected at De Bilt, Netherlands) [29], and sample SdAR-M2, that corresponded to a metal-rich sediment produced by the US Geological Survey [30]. For the verification check to be acceptable, it was considered that the measured value for each target analyte in these samples should be within $\pm 20 \%$ RD of the true value [15]. The mentioned major elements could present a greater difference than trace elements between the real-total contents and the extractable contents in aqua regia, since they can be associated with silicate that is difficult to dissolve.

\subsection{Statistical Data Analysis}

Data were explored and transformed in the following way:

For each element, the relationships among the reported average values corresponding to MARSEP program (X (ae)) and the average reading from the SOIL (X (S)) or MINING (X (M)) methods of PXRF were assessed by plotting the data.

Multiple linear regression analysis was used to predict $X(a)$ as the dependent variable from $X(S)$ or X (M) content. This first adjustment consisted of a single linear regression equation. After this first adjustment, the residuals were calculated and their correlations with other elemental contents were determined. The parameters with higher and significant Pearson coefficient (usually Si (M) but also other major and trace elements) were then added one by one into the equation, and the process was repeated to look for additional significant independent variables. $\mathrm{X}(\mathrm{ae})$ data and the predicted values obtained from the regression equations, $X$ (predicted), were compared using a paired samples $t$-test and $99 \%$ confidence probability.

All statistical analyses were carried out with IBM $^{\circledR}$ SPPS ${ }^{\circledR}$ Statistics version 25 (IBM Corp., Chicago, IL, USA).

The correlation coefficient $(r)$ for both series of results should be 0.7 or greater for the PXRF data to be considered screening level data. If $r$ is greater than 0.9 and inferential statistics (the slope of the line $=1$ and the $y$-intercept $=0$ ) indicate the two data sets are statistically similar at the $95 \%$ confidence level, the data quality is definitive [15]. The empirical calibration (single or multiple linear regression equation) is considered quantitatively acceptable for a specific analyte if the correlation coefficient is greater than 0.98 [15].

The relative standard deviation, RSD, is the ratio as a percentage of the standard deviation, SD, and the mean concentration of an element. The relative difference, $\mathrm{RD}$, is the difference, as percentage, between the predicted and actual values. When the average RD was calculated, the absolute values were used.

\section{Results and Discussion}

A summary of the results obtained for the MARSEP samples using both methods, Mining and Soil, is shown in Table 1. The range of values for several elements extended over one order of magnitude, which indicated a high variability among the different materials analyzed. These extended ranges also allowed a sufficient set of data for calibration extending between the concentration ranges that are usually given in organic amendments. For most of the elements, the number of valid results in the MARSEP programme [31] was greater than 30 . 
Table 1. Comparison of ranges of elemental concentrations ( $\mathrm{mg} \mathrm{kg}^{-1}$ unless otherwise stated) determined using portable $\mathrm{X}$-ray spectrometry (PXRF).

\begin{tabular}{ccccccccc}
\hline \multirow{2}{*}{ Samples } & \multicolumn{9}{c}{ Method Soil } & \multicolumn{5}{c}{ Method Mining } \\
\cline { 2 - 9 } & $\mathbf{N}^{\mathbf{1}}$ & Min & Max & Mean & $\mathbf{N}^{\mathbf{1}}$ & Min & Max & Mean \\
\hline $\mathrm{LOI}^{2}$ & 32 & 24.1 & 90.0 & 52.0 & & & & \\
$\mathrm{Bal}^{3}$ & & & & & 32 & 70.6 & 92.5 & 77.7 \\
$\mathrm{As}$ & 20 & 2.6 & 18.5 & 9.8 & 14 & 4.7 & 10.0 & 7.2 \\
$\mathrm{Ba}$ & 23 & 45.4 & 406 & 177 & 24 & 79.5 & 489 & 244 \\
$\mathrm{Cr}$ & 21 & 30.4 & 441 & 94.0 & 25 & 92.6 & 326 & 170 \\
$\mathrm{Cu}$ & 31 & 12.0 & 426 & 150.6 & 27 & 29.2 & 768 & 294 \\
$\mathrm{Mn}$ & 28 & 106 & 631 & 418 & 27 & 105 & 680 & 312 \\
$\mathrm{Mo}$ & 23 & 3.2 & 22.7 & 5.2 & 10 & 2.9 & 16.2 & 5.0 \\
$\mathrm{Ni}$ & 18 & 23.0 & 78.6 & 36.8 & & $<\mathrm{LOD}$ & $<\mathrm{LOD}$ & $<\mathrm{LOD}$ \\
$\mathrm{Pb}$ & 25 & 14.3 & 236 & 69.8 & 24 & 12.9 & 240 & 66.3 \\
$\mathrm{Rb}$ & 32 & 8.7 & 59.9 & 26.8 & 32 & 4.3 & 38.0 & 17.2 \\
$\mathrm{Sr}$ & 32 & 44.2 & 292 & 170 & 32 & 44.6 & 296 & 172 \\
$\mathrm{Ti}$ & 32 & 68.5 & 4142 & 1664 & 32 & 97.7 & 2669 & 1200 \\
$\mathrm{~V}$ & 16 & 31.0 & 88.8 & 56.0 & 24 & 42.5 & 157 & 82.7 \\
$\mathrm{Zn}$ & 32 & 55.5 & 1122 & 419 & 32 & 59.0 & 1364 & 502 \\
$\mathrm{Zr}$ & 32 & 4.46 & 128 & 59.3 & 32 & 3.8 & 120 & 51.7 \\
$\mathrm{Al}{ }^{4}$ & & & & & 30 & 1.0 & 33.5 & 11.4 \\
$\mathrm{Ca}{ }^{4}$ & 32 & 33.6 & 145 & 79.2 & 32 & 26.4 & 118 & 61.0 \\
$\mathrm{Cl}{ }^{4}$ & & & & & 32 & 0.30 & 10.3 & 2.57 \\
$\mathrm{Fe}{ }^{4}$ & 32 & 0.9 & 147 & 29.9 & 32 & 1.4 & 130 & 33.3 \\
$\mathrm{~K}{ }^{4}$ & 32 & 3.74 & 159 & 28.5 & 32 & 2.56 & 94.9 & 15.9 \\
$\mathrm{Mg}{ }^{4}$ & & & & & 12 & 3.10 & 7.19 & 4.33 \\
$\mathrm{P}^{4}$ & & & & & 32 & 1.01 & 35.4 & 17.1 \\
$\mathrm{~S}^{4}$ & 32 & 2.22 & 77.6 & 14.6 & 32 & 3.64 & 92.8 & 18.0 \\
$\mathrm{Si}{ }^{4}$ & & & & & 32 & 4.08 & 159 & 59.2 \\
\hline
\end{tabular}

${ }^{1} \mathrm{~N}$, valid cases above limit of detection (LOD). ${ }^{2}$ LOI: Loss on ignition values in \%. Data from the MARSEP programme, not from PXRF measurements. ${ }^{3}$ Bal: Difference to $100 \%$ of the sum of all measured elements. ${ }^{4}$ Values in $\mathrm{g} \mathrm{kg}^{-1}$.

\subsection{Loss on Ignition (LOI)}

The LOI (i.e., organic matter content) is not directly determined by the PXRF instrument since the constituent elements of the organic matter $(\mathrm{C}, \mathrm{N}, \mathrm{O}, \mathrm{H})$ are beyond its capability. However, in the measurement method $\mathrm{M}$, a result called "Bal" (balance) is given, corresponding to the difference of up to $100 \%$ that has not been assigned to other elements. Bal and LOI were correlated (Figure 1), but the adjustment was weak ( $r^{2}=0.66$ for all the samples), and as can be seen in Table 1 , the values for Bal were much higher than those of LOI (average data from the MARSEP programme). These two parameters adjusted well (Figure 1, Equation (1)) if the $\mathrm{Si}(\mathrm{M})$ and $\mathrm{Ca}(\mathrm{M})$ contents were included in Linear Equation (1) (Table 2) between LOI and Bal. Equation (1) assumed that Bal can include organic matter (LOI) and elements such as oxygen associated with silica, clay and calcium carbonate, that are likely constituents of the compost and sewage sludge samples. The stoichiometric coefficients in Equation (1) would be -0.114 for $\mathrm{SiO}_{2},-0.171$ for $\mathrm{SiO}_{3}$ (silicates, clay), and -0.120 for $\mathrm{CaCO}_{3}$. The cause of the highest absolute values for the actual coefficients in Equation (1) is likely to be because other O-binding compounds, such as phosphates, sulfates, and iron and aluminum oxides, are included in the composition of the samples. The correlation coefficient for the predicted-LOI and actual-values, $r=0.982>0.98\left(r^{2}=0.965\right)$, indicated the validity of the adjustment for quantification. Additionally, the slope and the y-intercept of the relationship LOI-LOI (pred) met the quality criteria (slope $=1$ and y-intercept $=0$ ) whether for Equation (1), (2) or (3). 

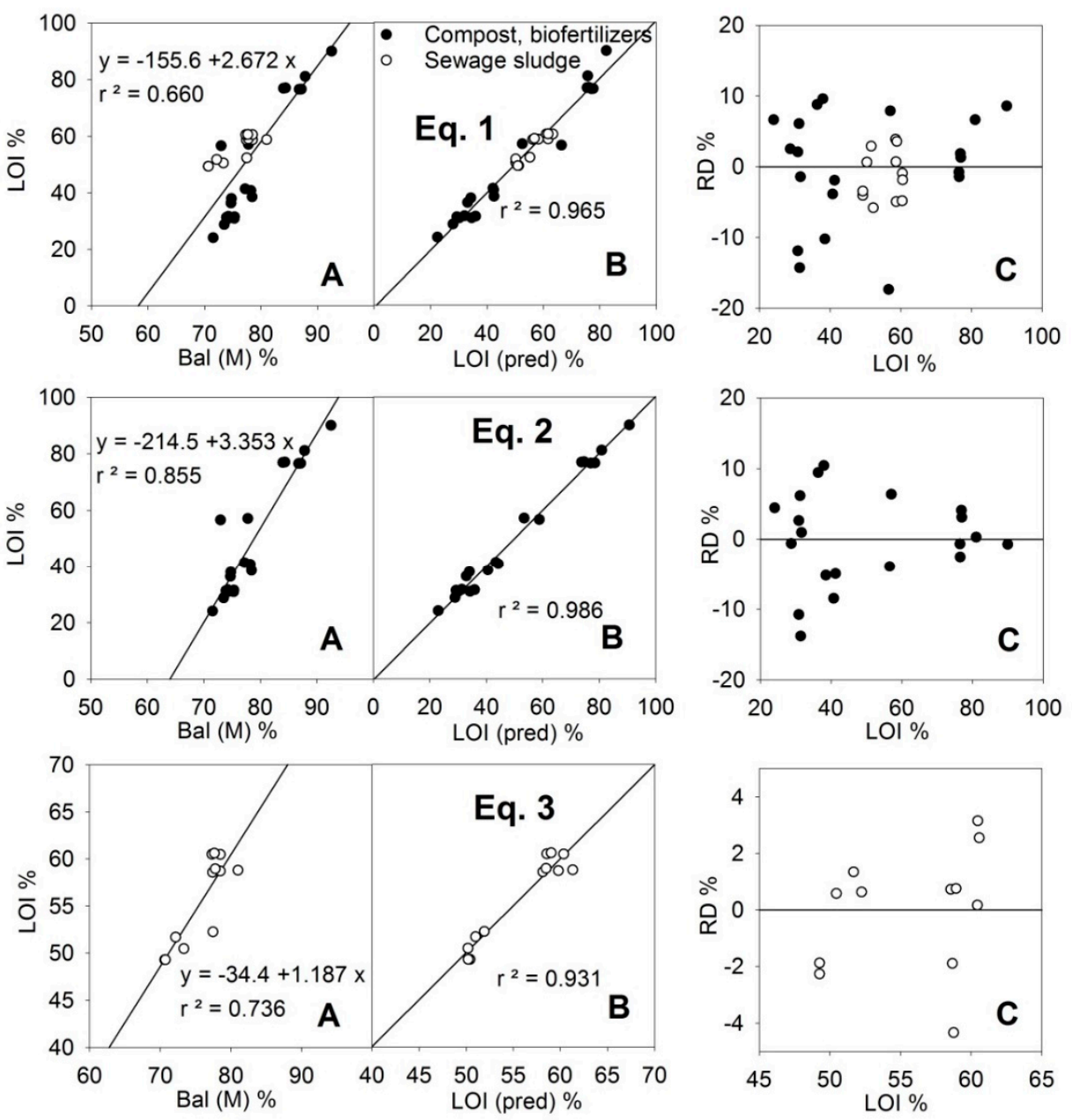

Figure 1. Relationships of Bal readings (difference to $100 \%$ of the sum of all measured elements) using PXRF and the LOI (loss on ignition) content in training samples of organic amendments (A). Adjustment of LOI predicted values using Equation (1): [LOI(pred)] = 0.998[Bal] $-0.248[\mathrm{Si}(\mathrm{M})]-0.176[\mathrm{Ca}(\mathrm{M})]$, Equation (2): $[\mathrm{LOI}($ pred $)]=1.145[\mathrm{Bal}]-0.272[\mathrm{Si}(\mathrm{M})]-0.268[\mathrm{Ca}(\mathrm{M})]-0.435[\mathrm{P}(\mathrm{M})]$, and Equation (3): $[\mathrm{LOI}(\mathrm{pred})]=0.885[\mathrm{Bal}]-0.258[\mathrm{Si}(\mathrm{M})]-0.032[\mathrm{Fe}(\mathrm{M})]($ Table 2$)(\mathrm{B})$ and relative deviations $(\mathrm{RD})$ of the predicted values $(\mathbf{C})$. ( $r^{2}$ is the coefficient of determination).

Table 2. Multiple linear equations for the prediction of $\mathrm{LOI}^{1}$ from the $\mathrm{Bal}^{2}$ readings obtained by the PXRF using the Mining (M) method.

\begin{tabular}{|c|c|c|c|c|c|c|c|c|}
\hline \multirow{2}{*}{ Equation } & \multirow{2}{*}[X(\text{pred})]{$=A[W(M)]+B[X(M)]+C[Y(M)]+D[Z(M)]$} & \multicolumn{4}{|c|}{$p$ Values } & \multicolumn{3}{|c|}{ Paired $t$-test } \\
\hline & & $p(\mathbf{A})$ & $p(\mathbf{B})$ & $p(\mathrm{C})$ & $p(\mathrm{D})$ & $r$ & Mean & $S d^{4}$ \\
\hline$(1)^{2,3}$ & {$[\mathrm{LOI}(\mathrm{pred})]=0.998[\mathrm{Bal}]-0.248[\mathrm{Si}(\mathrm{M})]-0.176[\mathrm{Ca}(\mathrm{M})]$} & 0.000 & 0.000 & 0.000 & & 0.982 & 52.0 & 3.31 \\
\hline (2) & $\begin{array}{c}{[\text { LOI }(\text { pred })]=} \\
1.145[\mathrm{Bal}]-0.272[\mathrm{Si}(\mathrm{M})]-0.268[\mathrm{Ca}(\mathrm{M})]-0.435[\mathrm{P}(\mathrm{M})]\end{array}$ & 0.000 & 0.000 & 0.000 & 0.000 & 0.993 & 49.8 & 2.53 \\
\hline (3) & {$[\mathrm{LOI}($ pred $)]=0.885[\mathrm{Bal}]-0.258[\mathrm{Si}(\mathrm{M})]-0.032[\mathrm{Fe}(\mathrm{M})]$} & 0.000 & 0.000 & 0.019 & & 0.965 & 55.8 & 1.24 \\
\hline
\end{tabular}

${ }^{1}$ LOI: Loss on ignition, i.e., organic matter content. Values in \%. ${ }^{2}$ [Bal]: Difference to $100 \%$ of the sum of all measured elements. ${ }^{3} \mathrm{Si}(\mathrm{M}), \mathrm{Ca}(\mathrm{M})$ and $\mathrm{P}(\mathrm{M})$ results expressed in $\mathrm{g} \mathrm{kg}^{-1} .{ }^{4} \mathrm{sd}$, standard deviation of the differences.

If the samples were separated according to their type (compost or sewage sludge) an even better adjustment could be obtained for the group of compost samples using Equation (2), which included a significant $\mathrm{P}(\mathrm{M})$ term, reducing the relative error of the predictions below $15 \%$ for all the sets of samples and below $10 \%$ if the LOI value was greater than $40 \%$ (Figure 1). For the samples of sewage sludge, the obtained adjustment (Equation (3), Figure 1) included an Fe(M) term, but it did not improve on Equation (1), although since these samples had a LOI value $>50 \%$ their relative errors were kept 
below $4 \%$. The Fe (M) term was due to the high content of this element in sewage sludge (see Fe in Figure 2).

To the best of the authors' knowledge, there is no previous study in which the organic matter content (LOI) of organic amendments could have been inferred directly from the PXRF data. It is worth mentioning here the works of Andrade et al. [32] and Silva et al. [33] in which they found that $\mathrm{Ca}, \mathrm{P}, \mathrm{Si}$ and $\mathrm{Fe}$, in line with the results presented here, were also among the most important variables for modeling the organic matter content in Brazilian soils. However, the $r^{2}$ values obtained in these studies were generally $<0.8$, possibly due the low organic content of the Brazilian soils studied.
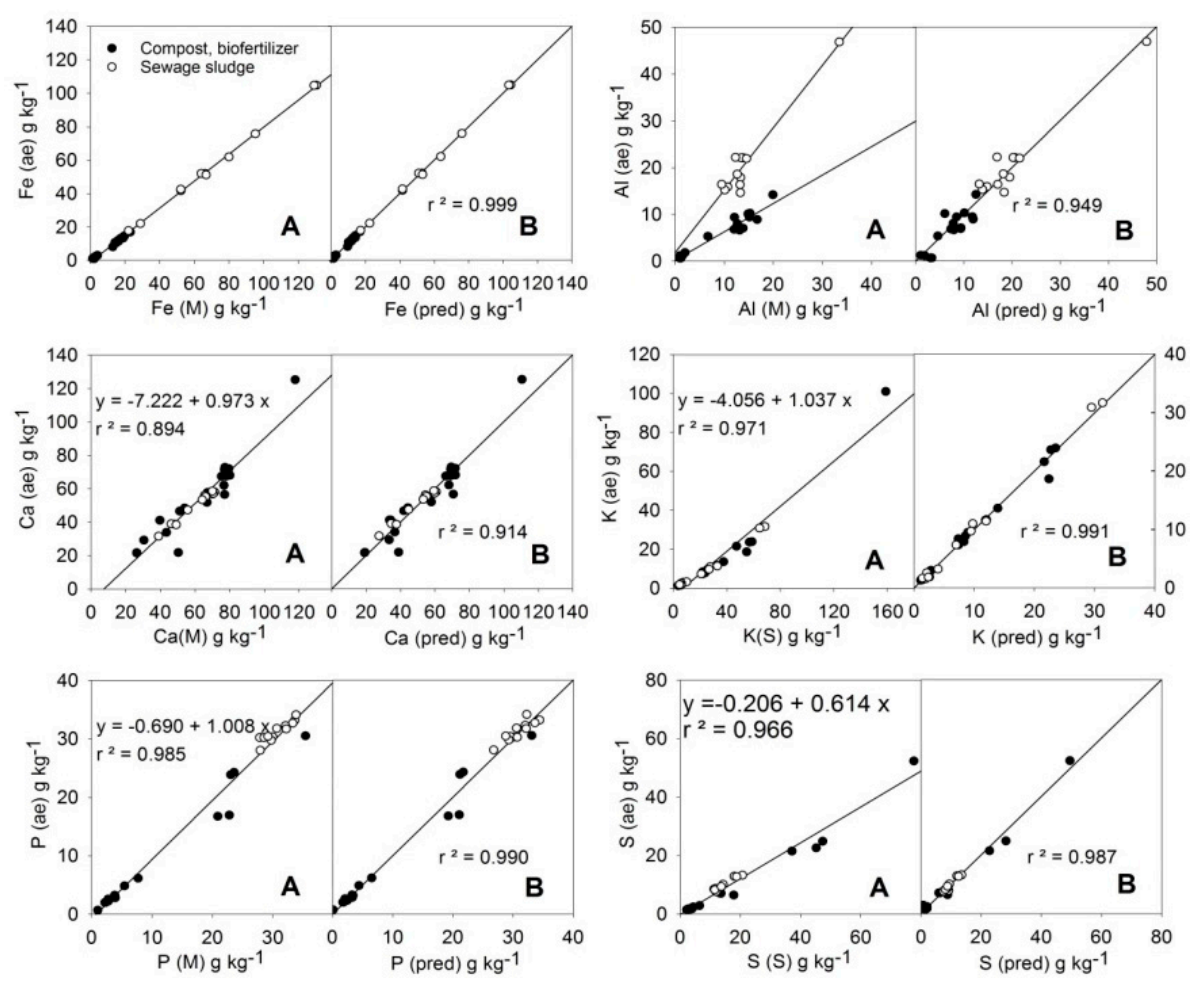

Figure 2. Relationships of PXRF readings of the major elements $\mathrm{Fe}, \mathrm{Al}, \mathrm{Ca}, \mathrm{K}, \mathrm{P}$, and $\mathrm{S}$ and their aqua regia-extractable contents in training samples of organic amendments $(\mathbf{A})$, and the adjustments of the predictions (B) of their aqua regia-extractable contents using the following multiple linear equations (Table 4): $[\mathrm{Fe}($ pred $)]=-0.242+0.804[\mathrm{Fe}(\mathrm{M})]-0.010[\mathrm{Si}(\mathrm{M})] ;[\mathrm{Al}($ pred $)]=2.077+1.622[\mathrm{Al}(\mathrm{M})]-$ $0.138[\mathrm{Si}(\mathrm{M})] ;[\mathrm{Ca}($ pred $)]=-15.049+1.039[\mathrm{Ca}(\mathrm{M})]+0.145[\mathrm{~K}(\mathrm{~S})] ;[\mathrm{K}($ pred $)]=-1.711+0.402[\mathrm{~K}(\mathrm{~S})]+$ $0.117[\mathrm{~S}(\mathrm{~S})] ;[\mathrm{P}($ pred $)]=-0.926+0.959[\mathrm{P}(\mathrm{M})]+0.033[\mathrm{Fe}(\mathrm{M})] ;[\mathrm{S}($ pred $)]=11.452+0.641[\mathrm{~S}(\mathrm{~S})]-0.162[\mathrm{Bal}]$ $+0.004[\mathrm{Cu}(\mathrm{S})]$.

\subsection{Macroelements ( $\mathrm{Fe}, \mathrm{Al}, \mathrm{Ca}, \mathrm{K}, \mathrm{P}, \mathrm{S}$ )}

A comparison of the contents of the certified samples SdAR-M2 and ISE 859, as determined by the M and S methods of PXRF, is shown in the Table 3. The EPA Method 6200 [15] indicated that the measured value for each target analyte should be within \pm 20 percent $(\% \mathrm{RD})$ of the true value for the verification check to be acceptable. The contents of Fe $(\mathrm{M})$ were satisfactory for both samples, while Fe (S) readings underestimated Fe content in the SdAR-M2 sample. The $\mathrm{Al}(\mathrm{M})$ readings underestimated its content in both samples. The $\mathrm{Ca}(\mathrm{M})$ contents were satisfactory for both samples. The $\mathrm{Ca}(\mathrm{S})$ readings were also satisfactory for both samples, although the RDs were greater than those corresponding to the $\mathrm{M}$ method. The K (M) content was satisfactory for the ISE 859 sample but slightly exceeded the $20 \%$ error limit for the SdAR-M2 sample. On the contrary, $\mathrm{K}(\mathrm{S})$ content was satisfactory for the SdAR-M2 sample but slightly exceeded the $20 \%$ error limit for the ISE 859 sample. Considering both methods, the average absolute RD was lower for the $\mathrm{S}$ method. The $\mathrm{P}(\mathrm{M})$ measurement was adequate for the 
ISE 859 sample, but the RD was quite high for the SdAR-M2 sample. Nevertheless, the P content of this sample $\left(0.35 \mathrm{~g} \cdot \mathrm{kg}^{-1}\right)$ was lower than the minimum P content in the organic amendments (1.01 $\mathrm{g} \cdot \mathrm{kg}^{-1}$, Table 1 ). The $S(\mathrm{M})$ readings were imprecise. The content of $S$ as read by the $S$ method was satisfactory for the ISE 859 sample and slightly exceeded the 20\% limit for the SdAR-M2 sample, but in this sample, the $S$ content was lower than the minimum in the amendments (Table 1). The content of Si (M) was satisfactory in SdAR-M2 and slightly exceeded the 20\% error limit in the ISE 859 sample. The $\mathrm{Mg}(\mathrm{M})$ content in ISE 859 was underestimated due to this element requiring air to be purged from the measurement window. In any case, the $\mathrm{Mg}$ element was not included in the following comparisons since a small number of data from PXRF were obtained, offering inconsistent results, possibly because they were close to the detection limit of the instrument. Additionally, in the case of $\mathrm{Cl}$, there was not reported data in the MARSEP reports.

Table 3. Real total contents $\left(\mathrm{g} \mathrm{kg}^{-1}\right)$ of the sediment samples ISE 859 and SdAR-M2 as determined using the Mining and Soil methods of the portable X-ray spectrometer (PXRF).

\begin{tabular}{|c|c|c|c|c|c|c|c|c|}
\hline & & \multicolumn{2}{|c|}{ Cert $^{1}$} & \multicolumn{3}{|c|}{ Mining } & \multicolumn{2}{|c|}{ Soil } \\
\hline & & Value & Value & $\mathrm{sd}^{2}$ & $\operatorname{RD}(\%)^{3}$ & Value & $\mathrm{sd}^{2}$ & $\operatorname{RD}(\%)^{3}$ \\
\hline \multirow{2}{*}{$\mathrm{Fe}$} & ISE 859 & 42.0 & 46.4 & 1.9 & 10.6 & 37.7 & 0.1 & -10.2 \\
\hline & SdAR_M2 & 18.4 & 18.5 & 0.1 & 0.3 & 13.9 & 0.1 & -24.3 \\
\hline \multirow{2}{*}{$\mathrm{Al}$} & ISE 859 & 55.3 & 37.5 & 0.1 & -32.2 & - & - & - \\
\hline & SdAR_M2 & 66.0 & 46.8 & 0.5 & -29.0 & - & - & - \\
\hline \multirow{2}{*}{$\mathrm{Ca}$} & ISE 859 & 33.9 & 35.0 & 0.0 & 3.1 & 39.5 & 0.2 & 16.6 \\
\hline & SdAR_M2 & 6.00 & 5.72 & 0.1 & -4.7 & 5.45 & 0.0 & -8.7 \\
\hline \multirow{2}{*}{$\mathrm{K}$} & ISE 859 & 15.3 & 12.3 & 0.0 & -19.2 & 18.5 & 0.0 & 21.5 \\
\hline & SdAR_M2 & 41.5 & 32.7 & 0.3 & -21.2 & 40.1 & 0.2 & -8.7 \\
\hline \multirow{2}{*}{$\mathrm{P}$} & ISE 859 & 4.08 & 4.09 & 0.03 & 0.3 & - & - & - \\
\hline & SdAR_M2 & 0.35 & 0.58 & 0.11 & 68.3 & - & - & - \\
\hline \multirow{2}{*}{$S$} & ISE 859 & 11.7 & 17.9 & 0.1 & 53.4 & 11.5 & 0.5 & -1.1 \\
\hline & SdAR_M2 & 0.97 & 1.56 & 0.04 & 60.6 & 1.19 & 0.08 & 22.6 \\
\hline \multirow{2}{*}{$\mathrm{Si}$} & ISE 859 & 213.0 & 167.5 & 0.3 & -21.3 & - & - & - \\
\hline & SdAR_M2 & 343.3 & 304.5 & 1.1 & -11.3 & - & - & - \\
\hline \multirow{2}{*}{$\mathrm{Mg}$} & ISE 859 & 8.42 & 5.42 & 0.45 & -35.7 & - & - & - \\
\hline & SdAR_M2 & 2.95 & - & - & - & - & - & - \\
\hline
\end{tabular}

${ }^{1}$ Certified value. ${ }^{2} \mathrm{sd}$, standard deviation. ${ }^{3} \mathrm{RD}$, percentage of difference to the certified value.

It was decided to use the readings Fe (M), $\mathrm{Ca}(\mathrm{M}), \mathrm{P}(\mathrm{M}), \mathrm{Si}(\mathrm{M}), \mathrm{K}(\mathrm{S})$, and S (S). The manufacturer's recommendations indicate that the $\mathrm{M}$ method is especially recommended for contents of metallic elements above $1 \%$.

Linear relationships among the average MARSEP values $(X(\mathrm{ae}))$ and the selected $X(M)$ or $X$ (S) readings can be observed in Figure 2 for the elements $\mathrm{Fe}, \mathrm{Al}, \mathrm{Ca}, \mathrm{K}, \mathrm{P}$, and $\mathrm{S}$. In the case of $\mathrm{Al}$, two different trends can be observed depending on the type of sample considered (compost or sewage sludge). The relationships between the average values of the MARSEP program ( $\mathrm{X}(\mathrm{ae})$, the vertical axis in each plot) and the calculated values from the best equations found (X (pred), the right horizontal axis in each plot) for the majority elements are shown in Figure 2. The obtained chemical linear equation for each element is shown in Table 4, and the results of the t-test among actual and predicted aqua regia-extractable contents are shown in Table 5. 
Table 4. Multiple linear equations for the prediction of aqua regia extractable contents of majority metal (X (pred)) from the readings obtained by the PXRF.

\begin{tabular}{|c|c|c|c|c|c|c|c|}
\hline \multirow{2}{*}{ Equation $^{1}$} & \multirow{2}{*}[X(\text{pred})]{$=A B[W(M, S)]+C[X(M, S)]+D[Y(M, S)]+E[Z(M, S)]$} & \multicolumn{6}{|c|}{$p$ Values } \\
\hline & & $p(\mathrm{~B})$ & $p(\mathrm{C})$ & $p(\mathrm{D})$ & $r$ & Mean $^{2}$ & $\mathrm{~N}^{4}$ \\
\hline (4) & {$[F e($ pred $)]=-0.242+0.804[\mathrm{Fe}(\mathrm{M})]-0.010[\mathrm{Si}(\mathrm{M})]$} & 0.000 & 0.005 & & 1.000 & 25.9 & 32 \\
\hline (5) & {$[\mathrm{Al}($ pred $)]=2.077+1.622[\mathrm{Al}(\mathrm{M})]-0.138[\mathrm{Si}(\mathrm{M})]$} & 0.000 & 0.000 & & 0.974 & 12.0 & 30 \\
\hline (6) & {$[\mathrm{Ca}($ pred $)]=-15.049+1.039[\mathrm{Ca}(\mathrm{M})]+0.145[K(S)]$} & 0.000 & 0.017 & & 0.956 & 52.1 & 32 \\
\hline (7) & {$[K($ pred $)]=-1.711+0.402[K(S)]+0.117[S(S)]$} & 0.000 & 0.000 & 0.000 & 0.995 & 9.53 & 31 \\
\hline (8) & {$[P($ pred $)]=-0.926+0.959[P(M)]+0.033[\mathrm{Fe}(M)]$} & 0.000 & 0.001 & & 0.995 & 16.6 & 32 \\
\hline$(9)^{3}$ & {$[S($ pred $)]=11.452+0.641[S(S)]-0.162[\mathrm{Bal}]+0.004[\mathrm{Cu}(S)]$} & 0.000 & 0.001 & 0.011 & 0.994 & 8.30 & 31 \\
\hline
\end{tabular}

${ }^{1}$ Readings from $\mathrm{M}$ or $\mathrm{S}$ method. ${ }^{2}$ Values in $\mathrm{g} \mathrm{kg}^{-1}$ except $\mathrm{Cu}(\mathrm{S})$ in $\mathrm{mg} \mathrm{kg}^{-1}$ and Bal in $\% .{ }^{3}$ Bal: Difference to $100 \%$ of the sum of all measured elements. ${ }^{4} \mathrm{~N}$, number of data points.

Table 5. Paired samples t-test between actual and predicted aqua regia-extractable elemental contents using the multiple regression equations.

\begin{tabular}{ccccccccc}
\hline & \multicolumn{3}{c}{ Paired Differences } & \multicolumn{5}{c}{$\mathbf{9 9 \%}$ CID $^{\mathbf{3}}$} \\
\cline { 2 - 8 } & Mean & Sd $^{\mathbf{1}}$ & sEM $^{\mathbf{2}}$ & Lower & Upper & $\mathbf{t}$ & Df $^{\mathbf{4}}$ & Sig $^{\mathbf{5}}$ \\
\hline $\mathrm{Fe}$ & 0.000 & 0.77 & 0.14 & -0.37 & 0.37 & 0.000 & 31 & 1.000 \\
$\mathrm{Al}$ & 0.000 & 2.17 & 0.40 & -1.09 & 1.09 & 0.000 & 29 & 1.000 \\
$\mathrm{Ca}$ & 0.000 & 6.52 & 1.15 & -3.16 & 3.16 & 0.000 & 31 & 1.000 \\
$\mathrm{~K}$ & 0.000 & 1.34 & 0.24 & -0.66 & 0.66 & 0.000 & 30 & 1.000 \\
$\mathrm{P}$ & 0.000 & 1.37 & 0.24 & -0.67 & 0.67 & 0.000 & 31 & 1.000 \\
$\mathrm{~S}$ & 0.000 & 1.13 & 0.20 & -0.56 & 0.56 & 0.000 & 30 & 1.000 \\
$\mathrm{Zn}$ & 0.000 & 0.77 & 0.14 & -0.37 & 0.37 & 0.000 & 31 & 1.000 \\
$\mathrm{Cu}$ & 0.000 & 7.53 & 1.30 & -3.58 & 3.58 & 0.000 & 30 & 1.000 \\
$\mathrm{~Pb}$ & 0.000 & 3.72 & 0.74 & -2.08 & 2.08 & 0.000 & 24 & 1.000 \\
$\mathrm{Sr}$ & 0.000 & 7.74 & 1.37 & -3.76 & 3.76 & 0.000 & 31 & 1.000 \\
$\mathrm{~V}$ & 0.000 & 3.32 & 0.83 & -2.45 & 2.45 & 0.000 & 15 & 1.000 \\
$\mathrm{Cr}$ & 0.000 & 6.82 & 1.49 & -4.24 & 4.24 & 0.000 & 20 & 1.000 \\
$\mathrm{Mn}$ & 0.000 & 17.7 & 3.35 & -9.27 & 9.27 & 0.000 & 27 & 1.000 \\
$\mathrm{Ba}$ & 0.000 & 39.0 & 8.13 & -22.9 & 22.9 & 0.000 & 22 & 1.000 \\
$\mathrm{Ni}$ & 0.000 & 6.14 & 1.44 & -4.20 & 4.20 & 0.000 & 17 & 1.000 \\
$\mathrm{As}$ & 0.000 & 1.08 & 0.24 & -0.69 & 0.69 & 0.000 & 19 & 1.000 \\
\hline
\end{tabular}

$1 \mathrm{sd}$, standard deviation of the differences. ${ }^{2} \mathrm{sEM}$, standard error of the mean of the differences. ${ }^{3} \mathrm{CID}, 99 \%$ Confidence Interval of the Difference. ${ }^{4} \mathrm{df}$, degrees of freedom. ${ }^{5}$ sig, two-tailed significance level.

The linearity was excellent for Fe. However, the slope of the regression was less than 1 and the $\mathrm{Fe}(\mathrm{ae})$ results were generally $20 \%$ lower than the $\mathrm{Fe}(\mathrm{M})$ readings. Caporale et al [17] found the soil aqua regia-extractable content of Fe was about $10-20 \%$ lower than the measured content using a similar PXRF instrument. This indicated a fraction of Fe was highly insoluble, likely due to the crystalline structures of the clay or other silicate compounds [17], which are probably also present in the compost and sludge samples. In the case that the $\mathrm{Si}(\mathrm{M})$ content was used to adjust the linear regression, Equation (4) in Table 4 was obtained, with the coefficient for the $\mathrm{Si}(\mathrm{M})$ term being statistically significant $(p(C)=0.005)$. The correlation coefficient $(r=0.9999)$ and the results of the $t$-test (Table 5) showed a very good fitting between the actual $\mathrm{Fe}$ (ae) and predicted-Fe values, indicating the validity of the adjustment for quantification.

The plot of $\mathrm{Al}(\mathrm{M})$ against the corresponding MARSEP results ( $\mathrm{Al}(\mathrm{ae}))$ showed two different patterns (Figure 2). Sewage sludge samples tended to have higher $\mathrm{Al}$ (ae) values than Mining PXRF readings, while compost and biofertilizer samples tended to give lower $\mathrm{Al}$ (ae) values than Mining PXRF readings. It is likely that in both amendment types, a part of their $\mathrm{Al}$ was associated with $\mathrm{Si}$ in clay structures, but the effect was different depending on the $\mathrm{Si}$ content of the sample (average $\mathrm{Si}$ (M) content was $73.1 \mathrm{~g} \cdot \mathrm{kg}^{-1}$ for the compost samples and $36.0 \mathrm{~g} \mathrm{~kg}^{-1}$ for the sewage sludge samples). If this factor was taken into account (Equation (5), Table 4), the coefficient obtained for the Si (M) effect was significant and only one regression line was obtained. The paired sample $t$-test (Table 5) showed 
no significant differences among actual and predicted $\mathrm{Al}$ (ae) contents, and the correlation coefficient $(r=0.974)$ was close to the limit $(r>0.98)$ to allow the quantification of this element despite the low performance of the direct $\mathrm{Al}(\mathrm{M})$ readings.

In the case of $\mathrm{Ca}$, the slope of the regression line (0.973) being close to 1 (Figure 2) indicated that there is not a large fraction of $\mathrm{Ca}$ associated with minerals not soluble in acid. However, the dots showed a certain dispersion, which is indicative of disturbing effects, as measured by PXRF. A better fit $\left(r^{2}=0.914\right)$ with significant coefficients was obtained considering K (S) contents as independent terms in the linear regression analysis (Equation (6)). The paired $t$-test (Table 5) indicated that predicted and actual Ca (ae) data did not differ at the 99\% confidence interval, but the value of $r=0.956<0.98$ did not allow quantification of this element. It is worth noting that the mismatch was largely due to the deviations of two points, one of them with a Ca content higher than the rest of the samples (see Figure 2). However, no anomaly was found in the general composition of these two samples that offers an explanation for their high deviations.

The slope of the regression line of K (ae) against readings of K (S) was 0.43 (Figure 2), indicating more than half of $\mathrm{K}$ was in acid-insoluble forms, likely associated to silicates. However, the best improvement in the adjustment was obtained if S (M) content was included in Equation (7) (Table 4). One $\mathrm{K}$ (ae) result $>100 \mathrm{~g} \cdot \mathrm{kg}^{-1}$, corresponding to an organic fertilizer, was not used in the adjustment. With the $\mathrm{S}(\mathrm{M})$ correction the value of $r=0.995$ indicated good quantification from the proposed equation. The paired t-test (Table 5) indicated that predicted and actual $\mathrm{K}$ (ae) data did not differ at the $99 \%$ confidence interval.

The fitting of the $\mathrm{P}(\mathrm{M})$ readings to the $\mathrm{P}$ (ae) data was good and direct (Figure 2), showing a value of slope close to 1 and $r=0.992>0.98$, allowing the quantification of this element with the correction of a low value for the y-intercept. However, a further improvement can be achieved if the term Fe (M) is incorporated into Equation (8) (Table 4), reaching $r=0.995$. The results of the $t$-test (Table 5) indicated equality among predicted and actual $\mathrm{P}$ (ae) data. The P-Fe relationship is likely based on the use of Fe salts used in wastewater treatment [34].

It is considered that light elements, i.e., $\mathrm{P}, \mathrm{K}, \mathrm{Ca}, \mathrm{Mg}$, contents are difficult to be measured with XRF, at least in soil samples [35]. In soils, Nawar et al. [35] obtained $r^{2}$ values of $0.92-0.95$ for $\mathrm{Mg}, \mathrm{P}, \mathrm{K}$, and $\mathrm{Ca}$ using the random forests model for calibration. Thus, the $r^{2}$ values obtained in the present study can be considered satisfactory, since the calibration procedure based on the spectra used by Nawar et al. [35] is more complex than the one used in this study.

For sulphur, the readings of the $S$ method were about $40 \%$ higher than the acid extractable contents (Figure 2). Equation (9) provided a good fit, including the terms Bal (organic matter content) and $\mathrm{Cu}$ (S) content, which were both significant (Table 4). The Bal correction was negative while the $\mathrm{Cu}$ (S) was positive. Likely, the $\mathrm{Cu}(\mathrm{S})$ term included the effect of several metals, such as $\mathrm{Pb}, \mathrm{Zn}$, and As, which also showed correlations with the residuals (data not shown). The value $r=0.994>0.98$ (Table 4) and the equality of the predicted and the actual values (Table 5) allow the quantification of $S$ (ae).

\subsection{Trace Elements}

The relationships between the average values of the MARSEP program (X (ae), vertical axis in each plot) and the values measured by the $S$ method of PXRF (X (S), left horizontal axis in each plot) or the calculated values from the best equations found ( $\mathrm{X}$ (pred), right horizontal axis in each plot) for the trace elements $\mathrm{Zn}, \mathrm{Cu}, \mathrm{Pb}, \mathrm{Sr}, \mathrm{Cr}, \mathrm{Mn}, \mathrm{Ni}, \mathrm{Ba}, \mathrm{As}$, and $\mathrm{V}$ are shown in Figure 3. The obtained chemical linear equation for each element is shown in Table 6 , and the result of the $t$-test among actual and predicted aqua regia-extractable contents is shown in Table 5. 

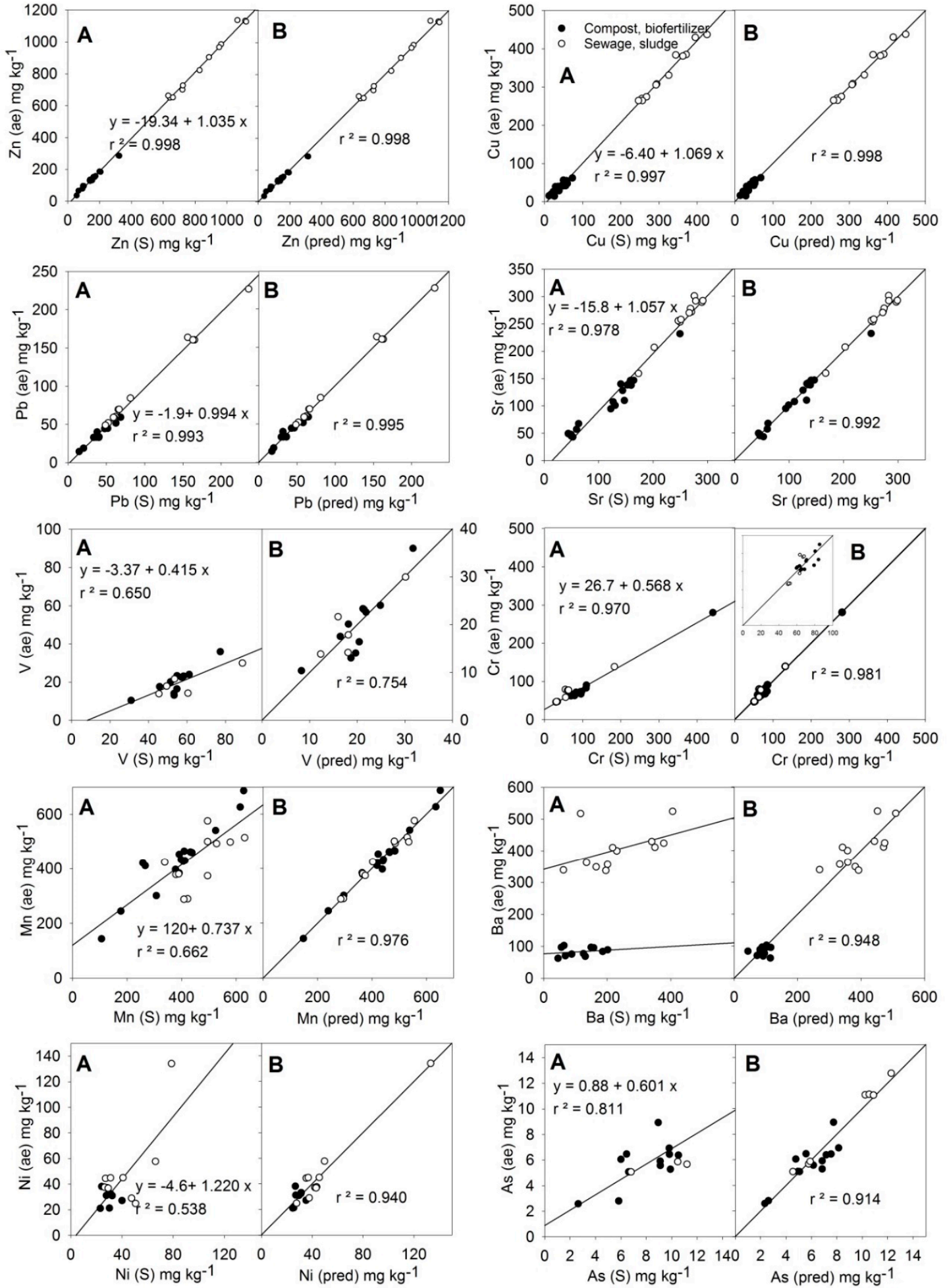

Figure 3. Relationships of PXRF readings of trace elements and their aqua regia-extractable contents in training samples of organic amendments (A) and the adjustments of the predictions (B) of their aqua regia-extractable contents using the multiple linear equations from Table 6. 
Table 6. Linear equations for the prediction of aqua regia extractable contents of trace metal (X(pred) from the readings obtained by the PXRF.

\begin{tabular}{|c|c|c|c|c|c|c|c|}
\hline \multirow{2}{*}{ Equation $^{1}$} & \multirow{2}{*}[X(\text{pred})]{$=A+B[W(S)]+C[X(M, S)]+D[Y(M, S)]+\ldots$} & \multicolumn{6}{|c|}{$p$ Values } \\
\hline & & $p(\mathbf{B})$ & $p(\mathrm{C})$ & $p(\mathrm{D})$ & $r$ & Mean $^{2}$ & $\mathrm{~N}^{4}$ \\
\hline (10) & {$[\mathrm{Zn}($ pred $)]=-19.34+1.035[\mathrm{Zn}(S)]$} & 0.000 & & & 0.999 & 414.7 & 32 \\
\hline (11) & {$[\mathrm{Cu}($ pred $)]=1.69+1.057[\mathrm{Cu}(\mathrm{S})]-0.103[\mathrm{Si}(\mathrm{M})]$} & 0.000 & 0.004 & & 0.999 & 154.6 & 31 \\
\hline (12) & {$[\mathrm{Pb}($ pred $)]=3.48+0.977[\mathrm{~Pb}(\mathrm{~S})]-0.059[\mathrm{Si}(\mathrm{M})]$} & 0.000 & 0.005 & & 0.998 & 67.5 & 25 \\
\hline (13) & {$[\operatorname{Sr}($ pred $)]=-1.65+1.055[\mathrm{Cu}(S)]-0.231[\operatorname{Si}(M)]$} & 0.000 & 0.000 & & 0.996 & 164.0 & 32 \\
\hline (14) & $[$ V (pred $)]=-7.09+0.377[V(S)]-0.060[\operatorname{Si}(M)]$ & 0.000 & 0.035 & & 0.868 & 19.8 & 16 \\
\hline (15) & {$[\mathrm{Cr}($ pred $)]=36.68+0.560[\mathrm{Cr}(\mathrm{S})]-0.117[\mathrm{Si}(\mathrm{M})]$} & 0.000 & 0.005 & & 0.991 & 80.1 & 21 \\
\hline (16) & {$[\mathrm{Mn}($ pred $)]=-506.1+0.847[\mathrm{Mn}(\mathrm{S})]-0.928[\mathrm{Fe}(\mathrm{M})]+$} & 0.000 & 0.000 & 0.000 & 0.988 & 428.2 & 28 \\
\hline (17) & $\begin{aligned} & 8.118[\mathrm{Bal}]-1.087[\mathrm{Ca}(\mathrm{M})]+0.975[\mathrm{Zr}(\mathrm{S})] \\
{[\mathrm{Ba}(\text { pred })]=} & 183.6+0.583[\mathrm{Ba}(\mathrm{S})]-3.045[\mathrm{Si}(\mathrm{M})]+13.25[\mathrm{Al}(\mathrm{M})]\end{aligned}$ & $\begin{array}{l}0.000 \\
0.000\end{array}$ & $\begin{array}{l}0.000 \\
0.000\end{array}$ & 0.000 & 0.973 & 250.9 & 23 \\
\hline (18) & {$[\mathrm{Ni}($ pred $)]=-397.9+0.949[\mathrm{Ni}(\mathrm{S})]+4.917[\mathrm{Bal}]+2.260[\mathrm{Al}(\mathrm{M})]$} & 0.000 & 0.000 & 0.000 & 0.970 & 40.3 & 18 \\
\hline$(19)^{3}$ & {$[$ As $($ pred $)]=3.857+0.525[\mathrm{As}(\mathrm{S})]-0.034[\mathrm{Ca}(\mathrm{M})]$} & 0.000 & $0.058^{\mathrm{ns}}$ & & 0.921 & 6.80 & 20 \\
\hline
\end{tabular}

${ }^{1}$ Readings from $\mathrm{M}$ or $\mathrm{S}$ method depending on the elelment. ${ }^{2}$ Values in $\mathrm{mg} \mathrm{kg}^{-1}$ except Si (M), Fe (M), Ca (M) and $\mathrm{Al}(\mathrm{M})$ in $\mathrm{g} \mathrm{kg}^{-1}$ and Bal in $\% .{ }^{3} \mathrm{Bal}$ : Difference to $100 \%$ of the sum of all measured elements. ${ }^{4} \mathrm{~N}$, number of data points. ${ }^{\text {ns }}$ no significative.

As can be seen in Figure 3, in the case of the metals $\mathrm{Zn}, \mathrm{Cu}, \mathrm{Pb}$, and $\mathrm{Sr}$, the PXRF instrument's direct readings quantitatively reproduced the acid-extractable contents, with $r>0.98$ (or $r^{2}>0.96$ ) except $r=0.978$ for Sr. Only minor adjustments of the y-intercept were necessary for $\mathrm{Zn}, \mathrm{Cu}$, and $\mathrm{Sr}$. No other element contents improved the $\mathrm{Zn}$ adjustment after the correction of the y-intercept (-19.3). Equation (10) (Table 6) yielded predicted results equivalent to the actual contents (results of $t$-test, Table 5).

For $\mathrm{Cu}, \mathrm{Pb}$, and $\mathrm{Sr}$, the introduction into the corresponding equations of a correction term, including the measurement of $\mathrm{Si}(\mathrm{M})$ (Equations (11)-(13), respectively, Table 6), was significant. In the case of $\mathrm{Cu}$ and $\mathrm{Pb}$ the improvement of the coefficient of determination $\left(r^{2}\right)$ was small because $\mathrm{r}^{2}$ was already close to 1 only with the single regression adjustment (Figure 3), but in the case of Sr, the adjustment $\left(r^{2}\right)$ improved appreciably. The $t$-test results (Table 5) and the $r$ values $>0.98$ (Table 6 ) indicated that the elements $\mathrm{Zn}, \mathrm{Cu}, \mathrm{Pb}$, and $\mathrm{Sr}$ can be quantified using the given equations.

For the elements $\mathrm{V}, \mathrm{Cr}, \mathrm{Mn}, \mathrm{Ba}, \mathrm{Ni}$, and $\mathrm{As}$, the values measured by the $\mathrm{S}$ method of PXRF $(X(\mathrm{~S})$ did not correspond to the contents given by the MARSEP program (X (ae) (Figure 3). In the case of V, $\mathrm{Cr}$, and As, the PXRF readings were greater than the MARSEP values (slope $<1$ ). In the case of Mn and $\mathrm{Ni}$, dispersion in the results was observed. In the case of $\mathrm{Ba}$, compost samples and sewage sludge samples behaved differently.

Fitting Equations (14), (15), and (17) for V, Cr, and Ba, respectively, included a correction term based on $\mathrm{Si}(\mathrm{M})$ content. As was observed in relation to the majority elements, the influence of $\mathrm{Si}$ content probably indicated the presence of silicates and clays from soil particles in the compost and sewage samples. Vanadium could be incorporated in the mineral structures of clays, $\mathrm{Cr}$ occurs in soils mainly in the immobile residual fraction, and Ba may be present in some silicate mineral as impurities [36]. The fitting for $\mathrm{V}(0.7<r=0.868<0.9)$ and the t-test (Table 5) qualified the quality of the predicted data was sufficient for it to be considered as screening level data. The $\mathrm{r}$ for $\mathrm{Cr}$ (Table 6) indicated its quantification was feasible using Equation (15). Equation (17) for Ba also included a significant $\mathrm{Al}(\mathrm{M})$ term, which likely is related to aluminosilicates. In the case of $\mathrm{Ba}, \mathrm{r}$ did not reach the quality criteria for quantification $(r=0.973<0.98)$, but the data were grouped into a single set and the level of the data quality was definitive $(r>0.9)$.

The relationship among Mn (ae) results and Mn (S) readings (Figure 2) was inadequate to allow the quantitative determination of this metal by the PXRF instrument, despite the contents of this metal being relatively high (106-631 $\mathrm{mg} \cdot \mathrm{kg}^{-1}$, Table 1). Equation (16) for Mn required several terms based on Fe (M) content, Bal (i.e., organic matter content), $\mathrm{Ca}(\mathrm{M})$, and $\mathrm{Zr}(\mathrm{S})$, which were all significant (Table 6). Manganese is a member of the iron family and both elements are closely associated with geochemical processes, and Mn oxides (as well as Fe oxides) are considered to be the most abundant compounds of the Earth's surface, which could explain why several correction 
factors were required [36]. The adjustment for Mn improved very notably with Equation (16), with the prediction of quantitative quality.

Similar to the case of $\mathrm{Mn}$, the relationship among the $\mathrm{Ni}(\mathrm{ae})$ results and $\mathrm{Ni}(\mathrm{S})$ readings was poor $\left(r^{2}=0.538\right.$, Figure 3). The equation for Ni (Equation (18), Table 6) included the corresponding reading of the $\mathrm{S}$ method, and two significant terms based on Bal (organic matter) and $\mathrm{Al}(\mathrm{M})$ readings. Although the quality of predicted Ni contents should be considered definitive ( $r=0.970$, Table 6$)$, there was a lack of dots in the range of intermediate contents $\left(60-120 \mathrm{~kg} \cdot \mathrm{kg}^{-1}\right)$ and additional samples will be needed to obtain a better chemical regression equation.

Equation (19) for As (Table 6) included a Ca (M) term, and allowed us to obtain definitive data $(r=0.921>0.9)$ for this element despite its low concentrations (average As (S) $=9.8 \mathrm{mg} \cdot \mathrm{kg}^{-1}$, Table 1 ). The guideline detection limit given by the manufacturer for this element is $10 \mathrm{mg} \cdot \mathrm{kg}^{-1}$ [37], so many of the readings obtained only slightly exceeded this limit.

\subsection{Deviations of Results}

The absolute values of the relative deviations (RD) among predicted and actual aqua regia-extractable contents for the considered elements are shown in Figure 4. The information from Figure 4 is summarized in Table 7 . The average RD was very high (48\%) for $\mathrm{Al}$, and then followed the order $\mathrm{Ba}, \mathrm{V}, \mathrm{Ni}, \mathrm{S}$, and $\mathrm{K}$, being less than $10 \%$ for the rest of the elements. Consequently, for the elements $\mathrm{Al}, \mathrm{Ba}, \mathrm{V}, \mathrm{Ni}, \mathrm{S}$, and $\mathrm{K}$ there were $13,6,5,5,4$, and 6 results surpassing the $20 \% \mathrm{RD}$ (Table 7 ). Nevertheless, as can be observed in Figure 4, for all the elements there was a sharply decay in the RD as their contents increased, and this $20 \%$ limit was exceeded only in the case of samples with the lowest concentrations of the elements considered. Hence, if the data with an RD greater than $20 \%$ are not included, the average RD was less than $10 \%$ for all the elements except Ni (last column in Table 7). The calculated content above which the RD will be lower than $20 \%$ (content for RSD $<20 \%$ ) is also shown in Table 7.

Table 7. Deviations between actual and predicted contents.

\begin{tabular}{|c|c|c|c|c|c|c|}
\hline & \multirow{2}{*}{$\operatorname{Rsd}(\%)^{1}$} & \multirow{2}{*}{$\begin{array}{l}\text { Content for } \\
\text { RSD }<20 \%{ }^{2}\end{array}$} & \multirow[b]{2}{*}{ EU Limit } & \multicolumn{3}{|c|}{ Actual Values } \\
\hline & & & & $n>20 \%^{3}$ & Average RD (\%) & $\begin{array}{c}\text { Average } \\
\text { RD- } n(\%)^{4}\end{array}$ \\
\hline LOI $^{5}$ & 6.4 & 16.6 & $27^{7}$ & 0 & 5.1 & 5.1 \\
\hline $\mathrm{Fe}^{5}$ & 3.0 & 3.9 & & 6 & 7.4 & 3.1 \\
\hline $\mathrm{Al}^{5}$ & 18.1 & 10.9 & & 13 & 47.9 & 7.5 \\
\hline $\mathrm{Ca}^{5}$ & 12.5 & 32.6 & & 2 & 9.7 & 6.9 \\
\hline $\mathrm{K}^{5}$ & 14.1 & 6.7 & $16.6^{7}$ & 6 & 10.4 & 6.5 \\
\hline $\mathrm{P}^{5}$ & 8.3 & 6.9 & $8.7^{7}$ & 2 & 9.8 & 6.9 \\
\hline$S^{5}$ & 13.6 & 5.7 & & 4 & 12.5 & 7.3 \\
\hline $\mathrm{Zn}{ }^{6}$ & 0.18 & 3.9 & $800^{8}$ & 1 & 4.5 & 3.9 \\
\hline $\mathrm{Cu}^{6}$ & 4.9 & 37.7 & $300^{8}$ & 3 & 9.8 & 5.5 \\
\hline $\mathrm{Pb}^{6}$ & 5.5 & 18.6 & $120^{8}$ & 1 & 5.7 & 5.0 \\
\hline $\mathrm{Sr}^{6}$ & 4.7 & 38.7 & & 2 & 4.6 & 3.4 \\
\hline $\mathrm{V}^{6}$ & 16.8 & 16.6 & & 5 & 15.4 & 7.6 \\
\hline $\mathrm{Cr}^{6}$ & 8.5 & 34.1 & & 0 & 8.1 & 8.1 \\
\hline $\mathrm{Mn}^{6}$ & 4.1 & 88.5 & & 0 & 3.1 & 3.1 \\
\hline $\mathrm{Ba}^{6}$ & 15.5 & 195 & & 6 & 16.2 & 8.2 \\
\hline $\mathrm{Ni}^{6}$ & 15.2 & 30.7 & $50^{8}$ & 5 & 14.8 & 10.5 \\
\hline As ${ }^{6}$ & 15.9 & 5.4 & $40^{8}$ & 2 & 10.0 & 8.3 \\
\hline
\end{tabular}

${ }^{1}$ RSD, relative standard deviation of the differences $=$ sd (Table 5$) \times 100 /$ mean MARSEP value. ${ }^{2}$ Content for RSD $<20 \%$. Limit of content above which RD will be lower than $20 \%=5 \times$ sd (Table 5 ). ${ }^{3} n>20 \%$, number of results with RD $>20 \% .{ }^{4}$ Average RD-n, average RD if the results with RD $>20 \%$ are eliminated. ${ }^{5} \mathrm{In} \mathrm{g} \mathrm{kg}^{-1} \cdot{ }^{6} \mathrm{In} \mathrm{mg} \mathrm{kg}^{-1}$. ${ }^{7}$ Minimum requirement for organic fertiliser type following [33]. ${ }^{8}$ Maximum allowable limit for organic fertiliser type following [33]. 

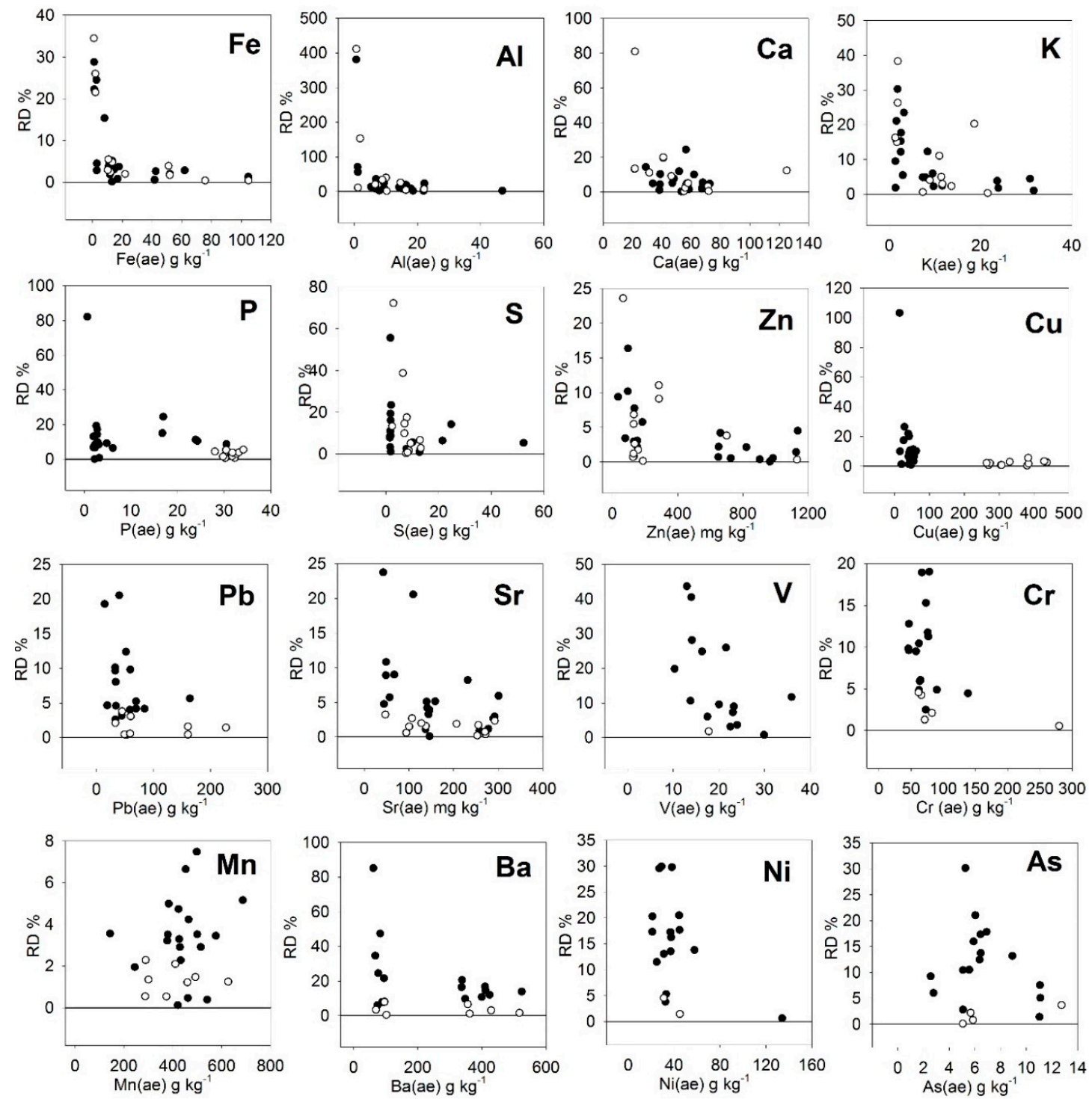

Figure 4. Absolute values of the relative deviations (RD) among predicted and actual aqua regia-extractable contents for major and trace elements.

The content for RSD $<20 \%$ was lower than the limits for macroelements or trace metals given in the EU regulations for organic fertilizers [38] (Table 7), which means that the PXRF technique could be valid to test the compliance of this type of product, at least in terms of quality control to be performed in the field or in the factory.

\subsection{Practical Implications of this Study}

The results of this study clearly indicate that rapid and accurate analysis of organic amendments using XRF instruments is possible. Considering that these types of analysis are high in cost, time consuming, and use disposable laboratory ware and potentially hazardous reagents used in the conventional laboratory methods for the characterization (nutrients, trace elements, and organic matter content), the proposed alternative would be not only viable but also recommended. Above all, the XRF analytical approach proposed would be very useful for quality control tasks in waste treatment facilities (composting plants, sewage treatment plants), organic fertilizer factories, nursery growing media, and for field control in small farms scale, i.e., urban agriculture or experimental or research trials. In these situations, we believe that the XRF technique represents a valuable decision support tool aimed at the proper management of farms/factories. 
The calibration equations obtained in this study were obtained with well characterised set of samples from composts, manure, sewage sludge, and biofertilizers from four countries in Central Europe. The applicability of the equations should be checked with other types of organic samples. Continuous and local or regional calibrations are also recommended to reinforce and generalize the relationships found or to find specifically-fitted ones. Interlaboratory trials are also desirable in order to adapt and improve the resolution of the technique for specific organic matrices and the cross-check of equipment from different brands and suppliers.

The XRF equipment used did not reach an adequate detection limit for elements such as $\mathrm{Cd}$ and $\mathrm{Hg}$ that are of interest in organic amendments. It would be necessary to look for calibrations to infer the contents of these elements. Such calibrations could be specific in terms of geographical area or sample type. It would also be useful to find calibrations allowing to infer other relevant properties for the characterization of amendments or organic fertilizers, such as electrical conductivity, as has been already done in soils [39]. Future work is also envisaged to investigate the potential combination of data from XRF with that obtained using other techniques like near- and mid-infrared spectroscopy that may provide complementary information to infer other variables relative to the composition or particular properties of organic amendments.

\section{Conclusions}

The results of this study have shown that in samples of organic amendments (composts, manures, biofertilizers, and sewage sludge), it is possible to determine the contents of aqua regia-soluble elements from the measurements made with a portable XRF analyzer. It was also possible to determine the content of organic matter (LOI) which is a novel achievement for this kind of analysers. The analyses were based on multiple linear equations that corrected the readings obtained for each element with the readings obtained from certain majority elements, such as $\mathrm{Si}, \mathrm{Fe}, \mathrm{Al}, \mathrm{Ca}, \mathrm{K}$, or $\mathrm{S}$. For $\mathrm{LOI}$ and the elements $\mathrm{Fe}, \mathrm{K}, \mathrm{P}, \mathrm{S}, \mathrm{Zn}, \mathrm{Cu}, \mathrm{Pb}, \mathrm{Sr}, \mathrm{Cr}$, and $\mathrm{Mn}$, the formulas used gave results of quantitative quality, while for $\mathrm{Al}, \mathrm{Ca}, \mathrm{V}, \mathrm{Ba}, \mathrm{Ni}$, and $\mathrm{As}$, the results can be considered definitive. The correction factors we used indicated that the lineal transformations found are based on the chemical composition of the sample matrix. Although this study was carried out with dried and ground samples, the speed of the scanning required for the analysis (3.5 $\mathrm{min}$ in total) would allow its application to heterogeneous dried raw samples by performing several repetitions in different aliquots of the same sample. Given that the correction factors only make use of the PXRF analyzer readings and no other laboratory parameters are required, the proposed method can be considered as autonomous and fully usable in field conditions. The PXRF instruments are achieving significant improvements in the analysis of numerous soil sample parameters, but their applicability and reliability for organic amendments were, until now, limited. This study highlights the potential of XRF portable analyzers for fast, cost-effective and reliable analysis of nutrients and heavy metals in organic amendments. The high coefficients of determination found for the predictions exceed those of many other applications in other fields. This study extends the fields of application of the XRF technique to the routine analysis of organic amendments.

Author Contributions: Conceptualization, R.L.-N.; Methodology, R.L.-N. and P.B.-D.; formal analysis, R.L.-N. and F.A.-P.; investigation, F.A.-P.; resources, P.B.-D.; writing—original draft preparation, R.L.-N.; writing-review and editing, R.L.-N., J.A.G.-P. and M.A.B.-L.; funding acquisition, J.A.G.-P.

Funding: This research was funded by the Spanish Ministry of Science, Innovation and Universities, and the European Regional Development Fund, European Union, (AEI/FEDER, UE), grant number CGL2016-78937-R.

Conflicts of Interest: The authors declare no conflict of interest. 


\section{Abbreviations}

$\begin{array}{ll}\text { ICPMS } & \text { Inductively coupled plasma-Mass Spectrometry } \\ \text { ICP-OES } & \text { Inductively coupled plasma-Optical emission spectrometry } \\ \text { ISE } & \text { International Soil Exchange } \\ \text { LOI } & \text { Loss on ignition } \\ \text { MARSEP } & \text { Manure and Refuse Sample Exchange Programme } \\ \text { PXRF } & \text { Portable X-ray fluorescence } \\ \text { RD } & \text { Relative difference: difference, as percentage, between the predicted and actual values } \\ \text { RSD } & \text { Relative standard deviation }\end{array}$

\section{References}

1. Martellozzo, F.; Landry, J.S.; Plouffe, D.; Seufert, V.; Rowhani, P.; Ramankutty, N. Urban agriculture: A global analysis of the space constraint to meet urban vegetable demand. Environ. Res. Lett. 2014, 9, 064025. [CrossRef]

2. Meharg, A.A. Perspective: City farming needs monitoring. Nature 2016, 531, S60. [CrossRef] [PubMed]

3. FAO. HABITAT III. Revised Zero Draft of the New Urban Agenda. In Proceedings of the United Nations Conference on Housing and Sustainable Urban Development, Quito, Ecuador, 18 June 2016.

4. Pfeiffer, A.; Silva, E.; Colquhoun, J. Innovation in urban agricultural practices: Responding to diverse production environments. Renew. Agric. Food Syst. 2015, 30, 79-91. [CrossRef]

5. Rogus, S.; Dimitri, C. Agriculture in urban and peri-urban areas in the United States: Highlights from the census of agriculture. Renew. Agric. Food Syst. 2015, 30, 64-78. [CrossRef]

6. Pearson, L.J.; Pearson, L.; Pearson, C.J. Sustainable urban agriculture: Stocktake and opportunities. Int. J. Agric. Sustain. 2010, 8, 7-19. [CrossRef]

7. Johnson, M.S.; Lathuillière, M.J.; Tooke, T.R.; Coops, N.C. Attenuation of urban agricultural production potential and crop water footprint due to shading from buildings and trees. Environ. Res. Lett. 2015, 10, 064007. [CrossRef]

8. Mok, H.F.; Williamson, V.G.; Grove, J.R.; Burry, K.; Barker, S.F.; Hamilton, A.J. Strawberry fields forever? Urban agriculture in developed countries: A review. Agron. Sustain. Dev. 2014, 34, 21-43. [CrossRef]

9. Alloway, B.J. Contamination of soils in domestic gardens and allotments: A brief overview. Land Contam. Reclam. 2004, 12, 179-187. [CrossRef]

10. Wei, B.; Yang, L. A review of heavy metal contaminations in urban soils, urban road dusts and agricultural soils from China. Microchem. J. 2010, 94, 99-107. [CrossRef]

11. Young, K.E.; Evans, C.A.; Hodges, K.V.; Bleacher, J.E.; Graff, T.G. A review of the handheld X-ray fluorescence spectrometer as a tool for field geologic investigations on Earth and in planetary surface exploration. Appl. Geochem. 2016, 72, 77-87. [CrossRef]

12. Weindorf, D.C.; Bakr, N.; Zhu, Y. Advances in Portable X-ray Fluorescence (PXRF) for Environmental, Pedological, and Agronomic Applications. Adv. Agron. 2014, 128, 1-45.

13. Shand, C.A.; Wendler, R. Portable X-ray fluorescence analysis of mineral and organic soils and the influence of organic matter. J. Geochem. Explor. 2014, 143, 31-42. [CrossRef]

14. Li, F.; Lu, A.; Wang, J. Modeling of Chromium, Copper, Zinc, Arsenic and Lead Using Portable X-ray Fluorescence Spectrometer Based on Discrete Wavelet Transform. Intern. J. Environ. Res. Public Health 2017, 14, 1163. [CrossRef] [PubMed]

15. EPA. Method 6200: Field Portable X-ray Fluorescence Spectrometry for the Determination of Elemental Concentrations in Soil and Sediment. Available online: https:/www.epa.gov/sites/production/files/2015-12/ documents/6200.pdf (accessed on 15 February 2019).

16. ISO. Soil quality-Screening Soils for Selected Elements by Energy-Dispersive X-ray Fluorescence Spectrometry Using a Handheld or Portable Instrument. Available online: https://www.iso.org/standard/ 53490.html (accessed on 12 February 2019).

17. Caporale, A.G.; Adamo, P.; Capozzi, F.; Langella, G.; Terribile, F.; Vingiani, S. Monitoring metal pollution in soils using portable-XRF and conventional laboratory-based techniques: Evaluation of the performance and limitations according to metal properties and sources. Sci. Total Environ. 2018, 643, 516-526. [CrossRef] 
18. Sharma, A.; Weindorf, D.C.; Wang, D.; Chakraborty, S. Characterizing soils via portable X-ray fluorescence spectrometer: 4. Cation exchange capacity (CEC). Geoderma 2015, 239-240, 130-134. [CrossRef]

19. Manohara, B.; Belagali, S.L. Evaluation of energy dispersive scanning electron microscopy and X-ray fluorescence techniques for analysis of compost quality. Anal. Methods 2017, 9, 253-258. [CrossRef]

20. Weindorf, D.C.; Sarkar, R.; Dia, M.; Haggard, B.; McWhirt, A.; Wooten, A.; Wang, H.; Chang, Q. Correlation of X-ray Fluorescence Spectrometry and Inductively Coupled Plasma Atomic Emission Spectroscopy for Elemental Determination in Composted Products. Compost Sci. Util. 2008, 16, 79-82. [CrossRef]

21. Weindorf, D.C.; Chakraborty, S.; Li, B.; Deb, S.; Singh, A.; Kusi, N.Y. Compost salinity assessment via portable X-ray fluorescence (PXRF) spectrometry. Waste Manag. 2018, 78, 158-163. [CrossRef]

22. McWhirt, A.; Weindorf, D.C.; Zhu, Y. Rapid analysis of elemental concentrations in compost via portable X-ray fluorescence spectrometry. Compost Sci. Util. 2012, 20, 185-193. [CrossRef]

23. Havukainen, J.; Hiltunen, J.; Puro, L.; Horttanainen, M. Applicability of a field portable X-ray fluorescence for analyzing elemental concentration of waste samples. Waste Manag. 2019, 83, 6-13. [CrossRef]

24. Healy, M.G.; Fenton, O.; Forrestal, P.J.; Danaher, M.; Brennan, R.B.; Morrison, L. Metal concentrations in lime stabilised, thermally dried and anaerobically digested sewage sludges. Waste Manag. 2016, 48, 404-408. [CrossRef] [PubMed]

25. Houba, V.J.G.; Uittenbogaard, J.; Pellen, P. Wageningen Evaluating Programmes for Analytical Laboratories (WEPAL), organization and purpose. Commun. Soil Sci. Plant Anal. 1996, 27, 421-431. [CrossRef]

26. European Committee for Standardization (CEN). Soil Improvers and Growing Media-Extraction of Aqua Regia Soluble Elements, EN 13650; British Standards Institution: London, UK, 2001.

27. European Committee for Standardization (CEN). Sludge, Treated Biowaste and Soil-Digestion of Aqua Regia Soluble Fractions of Elements, EN 16174; British Standards Institution: London, UK, 2012.

28. Cofino, W.P.; Van Stokkum, I.H.M.; Wells, D.E.; Ariese, F.; Wegener, J.W.M.; Peerboom, R.A.L. A new model for the inference of population characteristics from experimental data using uncertainties. Application to interlaboratory studies. Chemom. Intell. Lab. Syst. 2000, 53, 37-55. [CrossRef]

29. International Soil Analytical Exchange (ISE). Quarterlyy Report 2017.2; International Soil Analytical Exchange: Wageningen, The Netherlands, 2017.

30. International Association of Geoanalysts. Reference Material Data Sheet SdAR-M2 Metal-Rich Sediment; International Association of Geoanalysts: Nottingham, UK, 2015.

31. Wageningen Evaluating Programmes for Analytical Laboratories (WEPAL). MARSEP. Available online: http://www.wepal.nl/website/products/MARSEP.htm (accessed on 6 May 2019).

32. Andrade, R.; Silva, S.H.G.; Weindorf, D.C.; Chakraborty, S.; Faria, W.M.; Mesquita, L.F.; Guilherme, L.R.G.; Curi, N. Assessing models for prediction of some soil chemical properties from portable X-ray fluorescence (pXRF) spectrometry data in Brazilian Coastal Plains. Geoderma 2020, 357, 113957. [CrossRef]

33. Silva, S.H.G.; dos Santos Teixeira, A.F.; de Menezes, M.D.; Guilherme, L.R.G.; de Souza Moreira, F.M.; Curi, N. Multiple linear regression and random forest to predict and map soil properties using data from portable X-ray fluorescence spectrometer (pXRF). Ciênc. Agrotec. 2017, 41, 648-664. [CrossRef]

34. MetcalfandEddy, I. Wastewater Engineering: Treatment, Disposal and Reuse, 3rd ed.; McGraw-Hill Ltd.: New Delhi, India, 1991.

35. Nawar, S.; Delbecque, N.; Declercq, Y.; DeSmedt, P.; Finke, P.; Verdoodt, A.; Van Meirvenne, M.; Mouazen, A.M. Can spectral analyses improve measurement of key soil fertility parameters with X-ray fluorescence spectrometry? Geoderma 2019, 350, 29-39. [CrossRef]

36. Kabata-Pendias, A.; Pendias, H. Trace Elements in Soils ad Plants, 4th ed.; CRC Press: Boca Raton, FL, USA, 2011; p. 432.

37. Thermo Scientific. Thermo Scientific. Thermo Scientific Niton XRF Analyzers, Certificate of Analysis. In Part Number 143-00131, Rev. D.; Thermo Scientific: Boston, MA, USA, 2016. 
38. European Union. Regulation (EU) 2019/1009 of the European Parliament and of the Council of 5 June 2019 Laying down Rules on the Making Available on the Market of EU Fertilising Products and Amending Regulations (EC) No 1069/2009 and (EC) No 1107/2009 and Repealing Regulation (EC) No 2003/2003. Available online: https:/eur-lex.europa.eu/legal-content/EN/TXT/?uri=CELEX:32019R1009 (accessed on 17 July 2019).

39. Tóth, T.; Kovács, Z.A.; Rékási, M. XRF-measured rubidium concentration is the best predictor variable for estimating the soil clay content and salinity of semi-humid soils in two catenas. Geoderma 2019, 342, 106-108. [CrossRef]

(C) 2019 by the authors. Licensee MDPI, Basel, Switzerland. This article is an open access article distributed under the terms and conditions of the Creative Commons Attribution (CC BY) license (http://creativecommons.org/licenses/by/4.0/). 